\title{
Contents, Vol. 48, 1980
}

Founded 1938 as 'Schweizeiische Zeitschrift für allgemeine Pathologie und Bakteriologie' by A. v. Albertini, A. Grumbach and H. Mooser, continued as 'Pathologia et Microbiologia'

Editors Pathology J.R. Rüttner, Zurich

Microbiology F. Deinhardt, Munich

Immunology H. Ramseier, Zurich

Heterotransplantation L. Helson, New York, N.Y.

Differentiation A. Wolsky, New York, N.Y.

Co-Editors

Pathology R. Hess, BerneP. Vassalli, Geneva

M. Kyogoku, Sendai M.A. Spycher, Zurich G. Zbinden, Zurich

Microbiology H. Baer, Gainesville, Fla. J. Oxford, London

I. Gresser, Villejuif R. Rott, Giessen

A. Harboe, Oslo R.G. Webster, Memphis, Tenn.

J. Lindenmann, Zurich H. Mäkelä, Helsinki R. Zinkernagel, Zurich

Immunology H. Binz, Zurich R.T. Smith, Gainesville, Fla.

D.G. Braun, Basel J. Sprent, Philadelphia, Pa.

E. Diener, Edmonton E. Wecker, Würzburg

G.F. Mitchell, Melbourne H. Wigzell, Uppsala

He tero tran splan ta tion $\quad$ B.C. Giovanella, Houston, Tex. $\quad$ N.D. Reed, Bozeman, Mont.

D.P. Houchens, Columbus, Ohio J. Rygaard, Copenhagen

I. Lefkovits, Basel S. Shin, Bronx, N.Y.

T. Nomura, Kanagawa CO. Povlsen, Copenhagen B.C.M. Sordat, Lausanne

DifferentiationM. Balls, Nottingham D.J. Pizzarello, New York, N.Y.

R. Chandebois, Marseille G.V. Sherbet, Newcastle-upon-Tyne

G. Csaba, Budapest T. Yamada, Lausanne

S.Karger $\cdot$ Basel $\cdot$ München $\cdot$ Paris $•$ London $\cdot$ New York $\cdot$ Sydney

All rights reserved.

No part of this publication may be translated into other languages, reproduced or utilized in any form or by any means, electronic or mechanical, including photocopying, recording, microcopying, or by any information storage and retrieval system, without permission in writing from the publisher.

S. Karger AG, P.O. Box, CH-4009 Basel (Switzerland) Printed in Switzerland by Thür AG

Offsetdruck, Pratteln

Contents Vol. 48, 1980

No. 1

Ultrastructural Changes of Capillaries in Chronic Venous Insufficiency

Wenner, A.; Leu, H.J.; Spycher, M., and Brunner, U 1

A Cytofluorometric Analysis of Polymer-Induced Mast Cell Secretion 
Gustafsson, B. and Enerbäck, L 15

Action of Interferon on Aged Chick Embryo Cells. Contrast of in vivo and in vitro Studies

Martin, B.A.B.; Kroath, H.; Jungwirth, C; Hofschneider, P.H.; Bodo, G., and

Wengler, G 31

Primary Immune Response of Mouse Spleen Cells in a Serum-Free System: the Role of 2-

Mercaptoethanol

Burger, M.; Hess, M.W., and Cottier, $\mathrm{H} \quad 45$

Cells Transformed by Transfer of Isolated Chromosomes from Virus-Transformed or

'Spontaneous' Tumor Cells. I. Biological Properties and Transplantabuity in Nude Mice

Persuy, M.-A.; Ermonval, M.; Suarez, H.-G.; Daya-Grosjean, L.; Nardeux, P.;

Giovanella, B.C.; Kay, A.C., and Cassingena, R 51

Adenosine 3',5'-Cyclic Monophosphate and Guanosine 3',5'-Cyclic Monophosphate Levels in

Tumour, Plasma and Urine during the Growth of a Fibrosarcoma in Hamsters

Latner, A.L.; Patterson, S.W., and Turner, G.A 66

Study on Agglutination of Mouse Mammary Carcinoma (FM3A) Cells Induced by Egg

Agglutinin of Rana catesbiana

Takeda, S.; Kubota, K., and Matsuzawa, T 75

Book Reviews $\quad 85$

Announcement 88

No. 2

Quantitative Histochemical Changes in Intervertebral Discs in Diabetes

Aufdermaur, M.; Fehr, K.; Lesker, P., and Silberberg, R 89

Search for Mammalian Type-C Retrovirus Polypeptides on Infected Animal Cells and

Human Tumor Cell Lines Using Interspecies-Reacting Antibodies

Schneider, J.;Hunsmann, G., and Deinhardt, F 95

Contents

IV

Attempts to Transform Primate Cells in vitro by Herpes Simplex Virus

Marczynska, B.;McPheron, L.;Wilbanks, G.D.;Tsurumoto, D.M., and

Deinhardt, F 114

Statistical Methods for Measuring and Comparing Treatment Efficacies: Applications

to Nude Mice Experimentation

Lesser, M.L.;Braun, H.I., and Helson, L 126

Growth Curves of Three Human Malignant Tumors Transplanted to Nude Mice

Spang-Thomsen, M.; Nielsen, A., and Visfeldt, J 138

Ultrastructural Changes in the Embryonic Cells of the Frog Microhyla ornata after

Cytochalasin H Treatment

Wadekar, G.;Dastur, D.K., and Mulherkar, L155

Book Reviews $\quad 167$

No. 3

Effects of Retinoic Acid on the Human Lymphocyte Response to Mitogens

Abb, J. and Deinhardt, F 169

Lymphokine Production in Primary Mixed Lymphocyte Reactions. I. Characteristics of

Responding and Stimulating Cells

Landolfo, S.; Di Matteo, C; Capusso, A.; Negro-Ponzi, A., and Forni, G 180

Generation of Antibody Diversity Subsequent to Antigenic Stimulation 
Obel, J 191

Tumor Promoter Induces Loss of Anchorage Dependence in Human Skin Fibroblasts from Individuals Genetically Predisposed to Cancer

Kopelovich, L. and Bias, N.E 207

Cell Kinetic Study of Human Cancers Transplanted to Nude Mice

Ikeuchi, S.; Shimosato, Y.; Kameya, T.; Watanabe, S.; Kakegawa, T., and Abe, O.. 218 TwentyThree New Human Tumor Lines Established in Nude Mice

Fogh, J.;Orfeo, T.;Tiso, J.; Sharkey, F.E.;Fogh, J.M., and Daniels, W.P 229

Durable Sensitization of Hormone Receptors during Differentiation in Regenerating Planarians

by Treatment with Homologous or Analogous Hormone Molecules

Csaba, G. and Kádár, M 240

No. 4

Effects of Blood Pressure Reduction on the Ultrastructure of the Adrenal Cortex of the

Spontaneously Hypertensive Rat

Frink, R.;Krupp, P.P.; Root, D.T., and Warshaw, D.M

Effects of Irradiation on the in vitro Immune Response

Anderson, R.E. and Lefkovits, 1255

Contents

$\mathrm{V}$

Animal Model for Small Cell Carcinoma of the Lung. Effect of Immunosuppression and Sex of Mouse on Tumor Growth in Nude Athymic Mice

Pettengill, O.S.; Curphey, T.J.; Cate, C.C.; Flint, C.F.; Maurer, L.H., and

Sorenson, G.D279

Fetal Isoenzyme Expression of Heterotransplanted HeLa Cells in Nude Mice

Singer, R.M.; Leahy, E.M., and Gershwin, M.E 298

Clonal Differences in Generation Times of GPK Epithelial Cells in Monolayer Culture

Rüey, P.A. and Hola, M 310

No. 5

Acid and Alkaline Phosphatase in Macrophages of Tenebrío molitor Larvae Stimulated with

Asbestos. Part IV

Donna, A.; Betta, P.G., and Lanfranco, G 321

Age-Related Histochemical and Histological Changes in the Knee-Joint Cartilage of C57B1

Mice and Their Significance for the Pathogenesis of Osteoarthrosis. I. Oxidative Enzymes

Pataki, A.; Rüttner, J.R., and Abt, K 329

Cryo-Ultramicrotomy as a Tool for the Assessment of Doxorubicine Cardiotoxicity in Rats

Holdegger, C. and Zbinden, G 349

In vitro DNA Synthesis in Lymphocytes from DNCB Contact-Sensitive Guinea Pigs

Polak, L 356

Collagenase Inhibitors Retarding Invasion of a Human Tumor in Nude Mice

DeVore, D.P.; Houchens, DP.; Ovejera, A.A.; Dill, G.S., Jr., and Hutson, T.B. . . 367

Differentiation of Mouse Neuroblastoma Cells under Increased Oxygen Tension

Erkell, L.J 374

A Note on the Transformation of the dbrB Carcinoma

Fardon, J.C.; Williamson, D., and Freidel, J.F 381

A Comparison of the Electrokinetic Properties of Metastasizing and Non-Metastasizing Forms of a Hamster Lymphosarcoma 
Turner, G.A.; Sherbet, G.V., and Wildridge, M

No. 6

Possible Significance of Changes in the Energy Metabolism for the Release of Liver Lactate

Dehydrogenase and for the Uptake and Incorporation of ['4C]-Orotic Acid into Liver

Ribonucleic Acid after Partial Hepatectomy

Yngner, T.; Bengtsson, G.;Carlberg, E.;Engelbrecht, C, and Wieslander, A393

A Correlated Thin Section and Freeze-Fracture Study of o-Phenylphenol-Induced Alterations in the Rat Liver

Robenek, H.;Meiss, R.; Themann, H., and Himmels, S 404

Contents VI

Induction of Syncytia by Simian Sarcoma Virus Type I (SSV-I/SSAV-I) in Several Human

Transformed Cell Lines

Ocho, M.;Ogura, H.; Tanaka, T.,andOda, T 421

Release of |32-Microglobulin by Human Tumors Grown in Nude Mice

DiPersio, L.; Dingle, S.; Michael, J.G., and Pesce, A.J 429

Thymocyte Reconstitution of Athymic and Athymic-Asplenic Mice: Graft Rejection and Antibody Synthesis

Lair, S.V. and Lozzio, B.B 439

Correlation between Macrophages and Their Membrane Fraction. Cytocidal Activities on

Neoplastic Cells

Hakim, A.A 445

Test for 'Miniature Flies' following Exposure of Drosophila melanogaster Larvae to Diagnostic

Levels of Ultrasound

Child, S.Z.;Carstensen, EX., and Davis, H.T 461

Effect of Urethane on Folate Contents of Chick Embryos Measured with a Microbial Assay

Gokhale, V. and Mulherkar, L 467

An Investigation of the Presence of Smooth Endoplasmic Reticulum and GERL during

Vitellogenesis in the Ovary of Drosophila melanogaster

Witkus, E.R.; Altman, L.G., and Taparowsky, J.A 473

Book Reviews 484

Author Index 486

Subject Index 488 